原著論文

\title{
物語要約の漫画コマ割生成への影響
}

高嶋 航大*, 鬼沢 武久**

* 筑波大学大学院システム情報工学研究科鬼沢研究室, ** 筑波大学大学院システム情報工学研究科

\section{Effect of Text Summarization on Generation of Scene Frame for Manga Drawing}

\author{
Kodai TAKASHIMA* and Takehisa ONISAWA** \\ * Onisawa Laboratory, Graduate School of Systems and Information Engineering, University of Tsukuba, \\ 1-1-1 Tennodai, Tsukuba, Ibaraki 305-8573, Japan \\ ** Graduate School of Systems and Information Engineering, University of Tsukuba, 1-1-1 Tennodai, Tsukuba, Ibaraki 305-8573, Japan
}

\begin{abstract}
This paper aims at the scene frame generation based on the summarization of a narrative text, and studies effect of text summarization on generation of scene frame for manga drawing. Scene frames are generated from a summary using four kinds of importance degrees, the importance degree of an entire narrative text, the importance degree of a story and the importance degree of the first appearance of a character in a story, the importance degree of the sentence location. Subjects experiments are performed in order to verify the effectiveness of the present approach of scene frames generation, and study effect of text summarization. Experimental results show the present system can generate understandable scene frames of Manga from the narrative text with the summarization rate level smaller than 0.4 .
\end{abstract}

Keywords : Generation of Comic, Manga, Text summarization

\section{1. はじめに}

2007 年 5 月, 外務省によって, ポップカルチャーの文化 活用の一環として, 海外で漫画文化の普及活動に貢献する漫 画作家を顕彰する「国際漫画賞」の創設が行われた $[1]$. このことに代表されるように, 日本では, 近年, 物語の $1 つ$ の形である漫画に対して注目度が高まっている。 また，海外 においても日本のストーリーマンガは「Manga」として普 及しており，eラーニングに活用されることも考えられてい る [2].このような背景もあり, コンピュータによって漫 画の自動生成, または漫画の執筆を支援する研究がいくつも 行われている，例えば，漫画のジャンルを指定することで, そのジャンルの特徵をもったコマ割を生成する研究 [3], キャラクター作成, プロット作成など漫画の初期段階を支援 する研究 [4]，ゲームのログから漫画を生成する研究 [5] などである. その一方で, 漫画の業界で盛んに行われている, 小説などの物語の漫画化を目的とした研究はあまり行われて いない.これはコンピュータに物語の印象や著者の考えを変 えないように漫画を描かせることが容易ではなく, 人が物語 に対して着目する点や, 意図した印象を読者に与える漫画の 描き方, 読みやすい漫画の描き方をコンピュータに理解させ るのが難しいことが一因となっている, しかし, 物語から漫 画を自動的に生成することができれば，ユーザに漫画の案を 提示できるという点で, ユーザに対して漫画執筆の支援が行 えるとともに，漫画を描くことができない人でも漫画を作る ことができるようになることから,教科書など他の分野への 漫画の応用が行いやすくなる.

物語からの漫画自動生成の研究の第一歩として, 物語テキ
ストを入力としてコマ割の生成を行う手法を提案した研究が あり [6], 被験者実験によって, 提案手法では, 物語を理 解する上で十分なコマを生成できていることが確認されてい る [6]. しかし, この研究では物語中に現れる登場人物の 動作のほぼ全てをコマとして描いているため, コマ割が必要 以上に長くなってしまうという久点がある。 そこで本研究で は，ユーザの入力する物語テキストの要約を考え，要約され た物語テキストを基にコマ割生成を行ない, 要約された物語 テキストがコマ割生成に与える影響を調べることを目的とす る。な扮本研究でいう漫画とは, 物語の展開を主に絵と台詞 によって表現したもので，画像同士に連続性があり，画像の 大きさや形などを変えることにより，その画像の重要性を表 しているものとする.

\section{2. システム概要}

図 1 に漫画のコマ割生成システムの流れを示す.

$$
\text { ユーザがシステムに物語テキストを入力すると, システム }
$$

は，ユーザが入力した物語テキストをあとの工程で処理しや すい形態にするために前処理プロセスで構文解析, 形態素解 析などを行い, 重要度計算プロセスで物語テキストの各文に 対して重要度付けを行う。その後, 物語要約プロセスで重要 度をもとに漫画として表現する物語の文を決定し，コマ生成 プロセスで動詞情報などを用いてコマの生成, コマ配置プロ セスでそれらのコマを紙面に配置する。このプロセスにより 生成されたコマ割の情報をシステムはユーザに提示する。 シ ステムが出力するコマ割りの例を図2に示す. 図2のように, システムはコマに絵を描かず，そのコマで描く情報をテキス トで示す。 


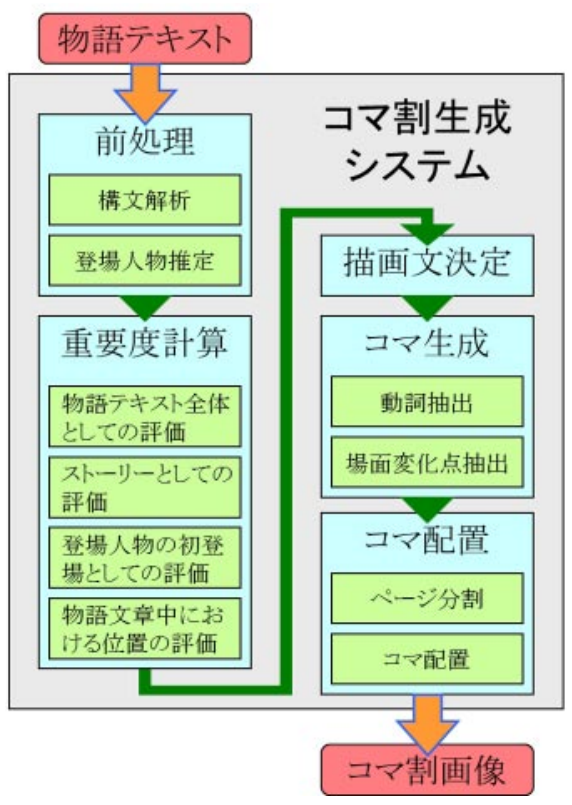

図1 コマ割生成システムの流れ

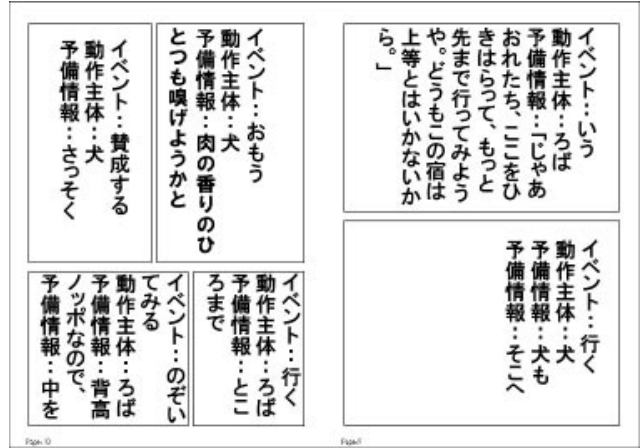

図2 システムが出力するコマ割りの例

\section{1 前処理プロセス}

前処理プロセスでは，物語テキストをあとの工程で使用し やすい状態にするため，形態素解析などを行う。また，あと のプロセスで使用される登場人物の推定も前処理プロセスで 行う. 形態素解析と構文解析には, 奈良先端科学技術大学院 大学が開発したChaSen とCaboChaを使用する $[7,8]$.

本研究において登場人物は，物語中からコマにする情報を 抽出するために使用され，また，物語テキストの各文の重要

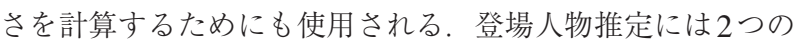
方法を用いる。1つは, 推定の基準となる動詞として「言う」 「話す」等の台詞を伴う動詞を用い, これらの動作の主語と なった単語, つまり, 動作主体と推定される単語を登場人物 とするものである。2つ目は，ストーリーとして重要な単語 を推定し，登場人物とするものである。重要な単語を推定す る手法として, 相良らのストーリー抽出の手法 [9] を用い, ストーリーの主軸と考えられる単語であるメインキーワード と，ストーリーの主軸に大きく関わる単語であるサブキー ワードを登場人物として推定するものである。用いるストー リー抽出の手法については, 重要度計算と同様の手法なた め, 2.2.2で説明する。これにより, 台詞を喋らない登場人
物や, 人物ではないが物語を説明する上で描くべき重要なも のも登場人物として抽出できる。

\section{2 重要度計算}

本研究では, 出力するコマ数の調整とコマの大きさを決定 する際の基準として，物語におけるそれぞれの文の重要度を 定義する．重要度として以下の4点を考える.

1. 物語テキスト全体の重要度

2. ストーリーとしての重要度

3. 登場人物の初登場の重要度

4. 物語テキスト中における位置の重要度

物語テキスト全体の重要度とは，文中に書かれている動作 や人物がどれほど重要であるかを重要度に反映させるための 度合いであり，文に含まれる単語がどれほど物語テキストの 中で重要であるかを基準として決定される，ストーリーとし ての重要度とは，文の物語中に扔ける重要な役割の有無を重 要度に反映させるための度合いである。物語全体に広く出現 しており，物語で意味を持って頻出している単語を基準とし て決定される。登場人物の初登場の重要度とは, 物語を展開 する上で必要な登場人物という存在を読者に印象付けるため の度合いである。物語テキスト中における位置の重要度と は，物語において重要な，始まりと終わりを要約に反映させ るための度合いである。

\subsection{1 物語テキスト全体の重要度}

本研究では砂山らの展望台システム [10］によって求め られた評価をもとに文の重要度を決定する。なお，本システ ムで評価する単語は動詞, 名詞, 形容詞, 未知語とする。た だし，未知語とはChaSenによって未知語と推定された， IPA辞書ipadic2.4［7］に含まれない単語である。展望台シ ステムでは単語を以下の3つの観点から評価している.

1. 周辺キーワードと呼び, 基礎的な概念としての評価

2. 中心キーワードと呼び, 基礎的な概念の中でも中心的 な主題としての評価

3. 特徵キーワードと呼び, 主題を特徴付ける単語として の評価

文書中における単語 $w$ の出現頻度をfrequency $(w)$ とする と, 単語 $w$ に対する周辺キーワードとしての評価值 $k e y 1(w)$ の值を式 (1)によって求める.

$$
\operatorname{key} 1(w)=\operatorname{frequency}(w)
$$

評価值 $k e y 1(w)$ の高い単語の上位の単語を中心キーワード 群とする.ただし上位とは, 文書中に現れる単語数の $4 \%$ 以内 で最大 5 個までに入るものとする。中心キワワード群を $S$, 単語 $w$ を含む文の数を $n(w)$, 単語 $w_{1}$ と単語 $w_{2}$ を含む文の数を $n\left(w_{1}, w_{2}\right)$ とすると，単語 $w$ に対する中心キーワードとしての 評価值 key2(w)の值を式 (2)によって求める.

$$
\operatorname{key} 2(w)=\prod_{s \in S} \frac{n(w, s)}{n(s)}
$$


なおこのとき, 中心キーワード群に含まれない単語が評 価值 $k e y 2(w)$ の上位 $4 \%$ の単語に含まれた場合, 新しい中心 キーワードとして中心キーワード群に追加し, 再度, 評価 值 $k e y 2(w)$ を計算する．上位 $4 \%$ の単語が全て中心キーワー ド群に含まれている場合, 特徵キーワードとしての評価值の 計算に移る。

中心キーワード群を $S$, 単語 $w$ を含む文の数を $n(w)$, 単語 $w_{1}$ と単語 $w_{2}$ を含む文の数を $n\left(w_{1}, w_{2}\right)$ とすると, 単語 $w$ に対す る特徵キーワードとしての評価值 $k e y 3(w)$ の值を式(3)に よって求める.

$$
\operatorname{key} 3(w)=\prod_{s \in S} \frac{n(w, s)}{n(w)}
$$

各文 $d$ の周辺キーワードとしての評価值 sentencel $(d)$, 中 心キーワードとしての評価值 sentence $2(d)$, 特徽キーワード としての評価值 sentence3 $(d)$ の值を式 $(4) \sim(6)$ によって求 める.

$$
\begin{aligned}
& \text { sentence } 1(d)=\sum_{w \in d} k e y 1(w) \\
& \text { sentence } 2(d)=\sum_{w \in d} k e y 2(w) \\
& \text { sentence } 3(d)=\sum_{w \in d} k e y 3(w)
\end{aligned}
$$

展望台システムでは，それぞれの評価值に対してランキン グ付けを行い, それらのランクをもとに重要文の決定を行っ ている。しかし, 本研究では文同士の重要度の差は大きな情 報であり, また, 他の重要度との統合を考え, それぞれの重 要度を正規化して加算することとする，文書 $D$ に含まれる 各文 $d$ の重要度 $W_{\text {Sentence }}$ を式（7）によって求める.

$$
\begin{aligned}
W_{\text {Sentence }}(d)= & \frac{\text { sentence } 1(d)}{\max _{d^{\prime} \in D} \text { sentencel }\left(d^{\prime}\right)}+ \\
& \frac{\text { sentence } 2(d)}{\max _{d^{\prime} \in D} \text { sentence } 2\left(d^{\prime}\right)}+ \\
& \frac{\text { sentence } 3(d)}{\max _{d^{\prime} \in D} \text { sentence } 3\left(d^{\prime}\right)}
\end{aligned}
$$

\subsection{2 ストーリーとしての重要度}

物語において, 特に重要な文が何であるかを知ることは, 後の物語展開を理解する上で重要である, そこで, 本研究で は相良らのストーリー抽出の手法 [9］を用いて主要なメイ ンストーリーとサブストーリーにあたる文を推定する。ここ で，サブストーリーとは，メインストーリーを補足する文の ことである.

\begin{tabular}{|c|c|}
\hline 条件 1 & 2段落以上に执いて，主語として用いられている \\
\hline 条件 2-1 & $\begin{array}{l}\text { 単語が, 1段落以上において, 高頻度で出現すること } \\
\text { を表す式 }(8) \text { を満たす }\end{array}$ \\
\hline 条件 2-2 & $\begin{array}{l}\text { 単語が，2段落以上において，一定の意味を持って用 } \\
\text { いられていることを表す式(9)を満たす }\end{array}$ \\
\hline 条件 3 & $\begin{array}{l}\text { メインストーリー中に出現する } \\
\text { (サブキーワード抽出時のみの条件) }\end{array}$ \\
\hline
\end{tabular}

まず，メインストーリーの抽出を行う，メインストーリー を抽出するため, メインキーワードの抽出を行う. 表 1 の条 件 1 を満たす単語の集合をメインキーワード候補 mainSet 1 , 表1の条件2-1かつ条件2-2を満たす単語の集合をメインキー ワード候補 mainSet2 とする.

\section{表1 キーワード条件}

$$
\begin{aligned}
& \text { freq }_{\text {seg }}(w) \geq \text { mean }_{\text {seg }}+\text { var }_{\text {seg }} \\
& \text { freq }_{\text {seg }}(w) \geq \text { mean }_{\text {seg }}
\end{aligned}
$$

ただし，freq seg $_{(}(w)$, mean $_{\text {seg }}$, var $_{\text {seg }}$ はそれぞれ，段落にお ける単語 $w$ の出現頻度, 段落の単語の平均出現頻度, 段落 の単語の出現頻度の分散である。

mainSet 1 を Set1 とし, Set1の各単語 $w$ の評価值 $E_{S e t 1}(w)$ を, テキスト中で主語となる回数に基づいた式（10）により定 義する。ただし subjectFreq text $_{\text {t }}(w)$ は単語 $w$ が主語として出現 する頻度である。

$$
E_{\text {Set } 1}(w)=\frac{\text { subjectFreq }_{\text {text }}(w)}{\max _{w^{\prime} \in \text { Set } 1} \text { subjectFreq }_{\text {text }}\left(w^{\prime}\right)} \quad(w \in \operatorname{Set} 1)
$$

mainSet2をSet2 とし, Set2の各単語 $w$ の評価值 $E_{S e t 2}(w)$ を式（11）によって定義する，ただし，freq $q_{t e x t}(w)$ は単語 $w$ が出現する頻度とする.

$$
E_{\text {Set2 }}(w)=\frac{\operatorname{freq}_{\text {text }}(w)}{\max _{w^{\prime} \in \operatorname{Set} 2} \operatorname{freq}_{\text {text }}\left(w^{\prime}\right)} \quad(w \in \operatorname{Set} 2)
$$

全ての単語について $E_{S e t 1}(w)+E_{S e t 2}(w)$ の值を計算する. このとき, メインストーリーを抽出するためのメインキー ワードは, $E_{S e t 1}(w)+E_{S e t 2}(w)$ の值の大きい上位から 3 つ単 語とする。

これらメインキーワードを中心キーワードとし, 先述し た展望台システムを使用し，それぞれの文に重要度順位を

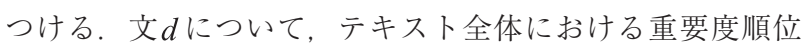
を $R_{\text {text }}(d, k e y), d$ が属する段落における重要度順位を $R_{\text {seg }}(d, k e y)$ とすると， $d$ の keyに関するストーリーにおける 重要度 $\operatorname{story}(d, k e y)$ を式 (12) 〜 (14) によって求める.

$$
\overline{R_{\text {text }}}(d, k e y)=\left\{\begin{array}{c}
R_{\text {text }}(d, \text { key }) \geq A v e_{\text {text }}(\text { key }) \text { のとき } \\
0.5-\frac{R_{\text {text }}(d, k e y)-A v e_{\text {text }}(k e y)}{M a x_{\text {text }}(k e y)-A v e_{\text {text }}(k e y)} \times 0.5 \\
R_{\text {text }}(d, k e y)<A v e_{\text {text }}(k e y) \text { のき } \\
0.5+\frac{A v e_{\text {text }}(k e y)-R_{\text {text }}(d, k e y)}{A v e_{\text {text }}(k e y)-\operatorname{Min}_{\text {text }}(d, k e y)} \times 0.5
\end{array}\right.
$$




$$
\overline{R_{\text {seg }}}(d, k e y)=\left\{\begin{array}{l}
R_{\text {seg }}(d, k e y) \geq A v e_{\text {seg }}(k e y) \text { のき } \\
0.5-\frac{R_{\text {seg }}(d, k e y)-A v e_{\text {seg }}(k e y)}{M a x_{\text {seg }}(k e y)-A v e_{\text {seg }}(k e y)} \times 0.5 \\
R_{\text {seg }}(d, k e y)<A v e_{\text {seg }}(k e y) \text { のき } \\
0.5+\frac{A v e_{\text {seg }}(k e y)-R_{\text {seg }}(d, k e y)}{A v e_{\text {seg }}(k e y)-\operatorname{Min}_{\text {seg }}(d, k e y)} \times 0.5
\end{array}\right.
$$

$\operatorname{story}(d, k e y)=\overline{R_{\text {text }}}(d, k e y)+\overline{R_{\text {seg }}}(d, k e y)$

ただし, Ave $e_{\text {text }}(k e y), A v e_{\text {seg }}(k e y), \operatorname{Max}_{\text {text }}(k e y), \operatorname{Max}_{\text {seg }}(k e y)$, $\operatorname{Min}_{\text {text }}(k e y), \operatorname{Min}_{\text {seg }}(k e y)$ はそれぞれ，テキスト中の各文dの $R_{\text {text }}(d, k e y) の$ 平均, 段落中の各文 $d の R_{\text {seg }}(d, k e y) の$ 平均, テ キスト中の各文 $d$ の $R_{\text {text }}(d, k e y) の$ 最大值，段落中の各文 $d の$ $R_{s e g}(d, k e y) の$ 最大值, テキスト中の各文 $d の R_{\text {text }}(d, k e y) の$ 最 小值，段落中の各文 $d の R_{\text {seg }}(d, k e y)$ 最小值である。

式 (14) で得た各文 $d$ の評価值 の大きいものから，全ての 文の10\%にあたる文をメインストーリーとする。

次にサブストーリーの抽出を行う。サブストーリーを抽出 するため, メインキーワードの抽出と同様の手法でサブキー ワードの抽出を行うが，このとき，メインキーワード抽出の 条件に加え，表 1 の条件 3 を考慮する，表 1 の条件 1 と条件 3 を満たす単語の集合をサブキーワード候補 subSet1，表1の 条件 2-1 と条件2-2, そして条件3を満たす単語の集合をサブ キーワード候補 subSet2とする。それぞれ，subSet1をSet1, subSet2をSet2 とし, 式（10）と（11）から, 全ての単語に ついて $E_{S e t 1}(w)+E_{S e t 2}(w)$ の值を計算する。 このとき, サブ ストーリーを抽出するためのサブキーワードは, $E_{S e t 1}(w)+E_{S e t 2}(w)$ の值の大きい上位から $3 つ の$ 単語とする.

サブキーワードからサブストーリー抽出を行う。サブス トーリーの抽出もメインストーリーと同様の手法で行う。

文dについて, メインキーワードをmainKey, サブキーワー ドを subKeyとすると, 文dのストーリーとしての重要度 $W_{\text {Story }}(d)$ を式（15）によって求める.

$$
W_{\text {Story }}(d)=\operatorname{story}(d, \text { mainKey })+\operatorname{story}(d, \text { subKey })
$$

\subsection{3 登場人物の初登場の重要度}

これまで登場していなかった登場人物が現れるという事象 は，「物語の流れの変化」の中でも特に重要である。そこで 本研究では, 物語の理解を容易にするため, それぞれの登場 人物が初めて出てくる文の重要度を大きくすることで要約文 に含まれやすし，また，そのコマを印象付けるようにコマが 大きくなりやすくする．登場人物の初登場の重要度 $W_{\text {Appear }}$ は，それぞれの登場人物が初めて出現した文においては 1.0 とし，それ以外の文は 0.0 とする。

\subsection{4 物語テキスト中における位置の重要度}

物語中において, 物語の始まりの部分はそのあとの物語 を理解するために必要な情報を多く含んでいる可能性が高
い.また一方で，終わりの部分は物語の締めくくりにあた る部分で，物語を中途半端に終わらせないために必要な情 報を含んでいる可能性が高い。このように物語中の位置を もとに文の重要度を推定する手法は，要約の分野で多く使 用されている [11].

そこで本研究でも物語中の位置における重要度を考慮す る. 文書 $D$ に含まれる文の数を sentenceNum, 先頭から $n$ 番 目の文 $d_{n}$ の物語の先頭部分としての評価を $E_{S t a r t}\left(d_{n}\right)$, 物語 の最終部分としての評価を $E_{E n d}\left(d_{n}\right)$, 物語全体を評価する值 を $E_{\text {Entire }}\left(d_{n}\right)$ とすると, 文 $d_{n}$ の物語テキスト中における位置 の重要度 $W_{\text {Location }}\left(d_{n}\right)$ を式（16）～（19）で求める.

$$
\begin{aligned}
& E_{\text {Start }}\left(d_{n}\right)=-\frac{1.0}{\text { Rate }_{\text {Start }}} \times \frac{n}{\text { sentenceNum }}+1.0 \\
& E_{\text {End }}\left(d_{n}\right)=\frac{1.0}{\text { Rate }_{\text {End }}} \times \frac{n}{\text { sentenceNum }}+\left(1.0-\text { Rate }_{\text {End }}\right) \\
& E_{\text {Entire }}\left(d_{n}\right)=\frac{\left(\frac{n}{\text { sentenceNum }}-0.5\right)^{2}}{100.0} \\
& W_{\text {Location }}\left(d_{n}\right)=\max \left(E_{\text {start }}\left(d_{n}\right), E_{\text {End }}\left(d_{n}\right), E_{\text {Entire }}\left(d_{n}\right)\right)
\end{aligned}
$$

なお，ここでRate Start $_{\text {咕 }}$ End は物語の先頭から，もしく は最後から何割の文を重視するか決定する定数である。ま た， $E_{\text {Entire }}$ は重要度の取り得る最低值を決定するとともに, それぞれの文に対して位置的な重要度の差をわずかにつけ, 全く同じ重要度の文があったとき，物語の前半においては先 に現れた文，後半においては後に現れた文を残しやすくする ための評価值である。

\section{3 物語要約プロセス}

漫画を制作する際，特に出版社への投稿や集団での漫画制 作の際，制作するべきぺージ数が決まっていることが多い. また，個人で制作する場合でも，あまりに長い漫画となって しまうと読者の負担となってしまう事から, 適度なページ数 が存在する。これらの理由から、ページ数、ひいては出力す るコマ数を調整する機構が必要である。そこで，重要度計算 プロセスで求められた重要度を用いて要約を行う。各文dの 重要度 $W(d)$ を式（20）で定義する。

$$
\begin{array}{r}
W(d)=W_{\text {Sentence }}(d)+W_{\text {Story }}(d)+ \\
\\
W_{\text {Appear }}(d)+W_{\text {Location }}(d)
\end{array}
$$

システムは，ユーザが指定した分量になるように，物語テ キストから重要度の高い順に文を抽出し，抽出された文の集 合が要約文となる。

\section{4 コマ生成プロセス}

本研究では，コマの生成の基準として動詞と場面を用い る.コマの生成の基本としては登場人物の動詞を用いるが, 多くの漫画において場面の変換点, 特に場所が変化する点で は，読者の理解をスムーズにするため，登場人物などが描か 
れていない風景描写がはさまれることが多い. なお,ここで 場面とは, 作中の時間, または場所が変化しない点で区切ら れた文章群であるとする。 そこで, 本研究においても, 場面 の変換点に風景のみのコマを挿入する．場面の変換点の推定 は,「やがて」「行きました」などの場所や時間の変化を示す 単語を基準に行う。基準とする単語は，木島らの挿絵生成の 研究 [12］を参考に決定している. 図3にその例を示す.

このプロセスを終え, 出力されるコマは, 以下の情報を 持つ.

1. 描く登場人物

2. 描く登場人物の動作

3. 描く動作に係る修飾

\section{5 コマ配置プロセス}

適切な大きさとしてコマ割を行うため, 各コマに重要度付 けを行い，その重要度をもとにコマの大きさを決定する。コ マに重要度付けを行う手法として，2.2節で述べた4つの重 要度のうち, 以下の3つを考慮する.

1. 物語テキスト全体の重要度

2.ストーリーとしての重要度

3. 登場人物の初登場の重要度

コマ配置プロセスでは, 1ページあたりのコマの重要度の 総和が, 全てのコマの重要度の平均值の 5 倍程度になるよう にページを分割する。これは, 近年の漫画において，1ペー ジあたりのコマ数が5〜6コマの構成が多く使われているた め, 平均的な重要度を持つコマが多いページでは，5６コ マに収まるようにするためである。ただし，漫画の見易さを 考慮し, 1ページあたりの最大のコマ数は10コマまでとする.

コマの配置は遺伝的アルゴリズム（GA）とレーベンバー グ・マルカート（LM）法［13］を用い最適化を行う. 染色 体 (変数) はページ分割点を個持つ. なお，ページ分割点と は, $\mathrm{X}$ 軸座標 $x, \mathrm{Y}$ 軸座標 $y$, 分割方向 $\theta$ の 3 つ変数を持つ 点のことである．X軸座標 $x, \mathrm{Y}$ 軸座標 $y$ はそれぞれ $[0,1]$ の実数值を取る. 分割方向 $\theta$ は, $\{0,1\}$ の2值を取り, 0 の場 合は横 (X軸) 方向, 1 の場合は縦（Y 軸）方向にページを 分割する、ページを分割する際は， $\mathrm{X}$ 軸座標 $x, \mathrm{Y}$ 軸座標 $y$ の点を通るように, 分割方向 $\theta$ の方向にページを分割する。 また，ページ分割点には順序があり，先に切った線と交叉す る場合, そこでページを切ることを終了する。これにより分 けられた領域が最終的なコマの配置となる。

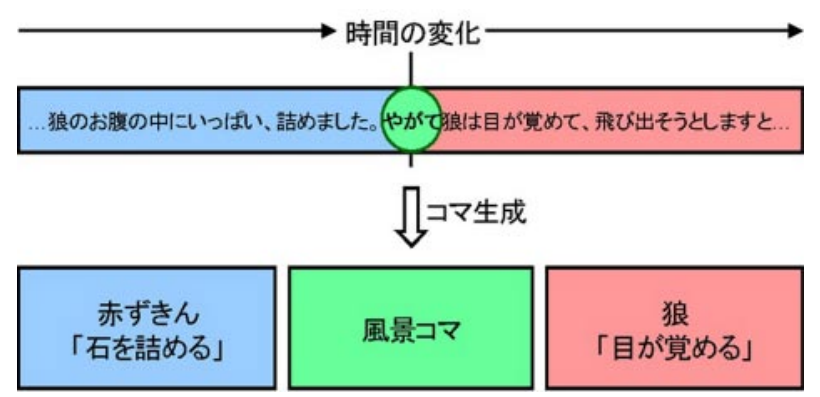

図3 場面変換点における風景コマの挿入
図4に染色体とコマ配置の例を示す。ページに配置するコ マの数が3つの時, ページ分割点は2つとなる. 図4の例では, まず, Point1からページを分割する. Point1が座標 $(0.25,0.25)$

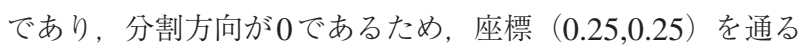
ように横方向にページを切る. 次に, Point 2 が座標 $(0.5,0.75)$ であり，分割方向が1であるため，座標 $(0.5,0.75)$ を通る ように縦方向にページを切る，このとき，Point1によって 切られた線と, Point2によって切る線が交差するため, Point2によって切る線はPoint1によって切られた線で止 まっている。これにより分けられた3つの領域がそれぞれコ マとなる、コマを読み進める順番, つまり, コマの情報を 入れる順番は, 横に切った場合は上が先に, 縦に切った場 合は右が先になる。この例の場合, 一番上のコマが初めの コマとなり，下部右が2番目のコマ, 下部左が 3 番目のコマ となる.

最適化の流れを図 5 に示す。最適化は各々のページについ て行う。まず，100個の初期個体の生成を行い，LM法を用 いてそれぞれの個体について最適化を行う。 その後, それ ぞれの個体を評価し，評価をもとに交叉，および突然変異 を行う。交叉にはランキング選択とエリート選択を採用す る。交叉を行う指標とするため, 評価值を非適合值とし, 非適合值の小さい順にランク付けを行う。親の選択はラン ク上位の個体から $[0,1]$ の一様乱数を生成し，0.5を上回っ た場合親として用いる。採用されなかった場合, 次のラン クの個体について, 同様の操作を行う. そのため, $r$ を個体 のランクとすると, 親として選択される確率 $P_{r}$ は式 (21) のようになる。 また, 最も非適合值が低かった個体は変化 させずに次の世代に残す。

$$
P_{r}=0.5^{r}
$$

交叉などの操作を終えたあと, システムはそれぞれの個体 について再度評価を行い, 非適合值が規定值以下になってい た場合，そこでそのページの最適化を終了する，規定值を下 回っていなかった場合, 再度LM法による最適化からやり直

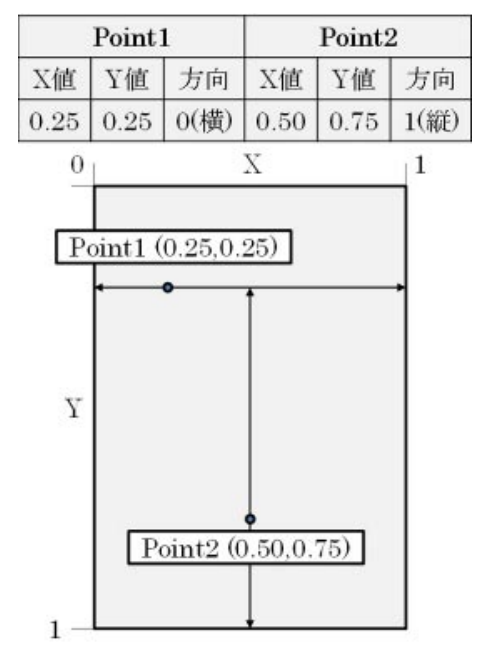

図4 コマ数3コマの場合の染色体とページの切り方の例 


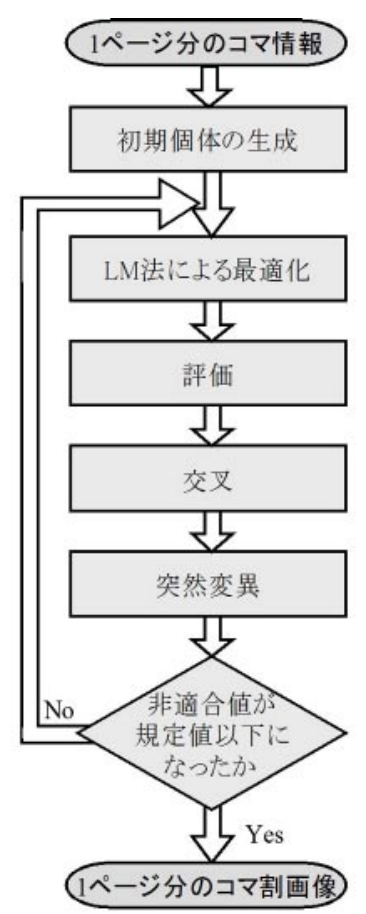

図5 最適化の流れ

す。このプロセスを終え,システムは最終的なコマ割画像を ユーザに出力する

非適合值を計算する評価関数として以下の 4 つを考える.

1. コマ同士のサイズの比率による評価

2. 最低サイズによる評価

3. 縦横比による評価

4. コマ同士の境界線による評価

\section{5 .1 コマ同士のサイズの比率による評価関数}

重要度の大きなコマほど大きくし, 重要度の小さなコマほ ど小さくするなど, 重要度とコマの大きさを比例させるた め, 式（22）を用いて評価する。ただし，ページ中のコマ の集合を $S$ とし, コマの数を $n$, コマ $s$ の重要度を $s_{\text {importance }}$, 面積を $s_{\text {Area }}$ とする.

$$
E_{\text {Ratio }}=\frac{\left(\sum_{s \in S}\left(\frac{s_{\text {importance }}}{\sum_{s^{\prime} \in S} s_{\text {importance }}^{\prime}}-\frac{s_{\text {Area }}}{\sum_{s^{\prime} \in S} s_{\text {Area }}^{\prime}}\right)^{2}\right)^{\frac{1}{2}}}{n}
$$

\section{5 .2 最低サイズによる評価}

コマに説明を書く際，一定以上のコマの大きさがなけれ ば, コマの内容を書くことは難しく, また, 読みにくくなる. そこでコマを一定以上の大きさとするため, 式 (23) の評 価関数を用い評価する。ただし, ページ中のコマの集合を $S$ とし, コマの数を $n$, コマsの横幅を $s_{\text {width }}$, 縦幅を $s_{\text {height }}$, 横

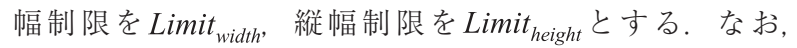

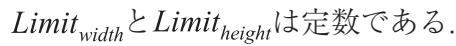

$$
\begin{gathered}
E_{\text {Size }}=\sum_{s \in S}\left(2-\frac{1}{1+\exp \left(-200 \times\left(s_{\text {width }}-\text { Limit }_{\text {width }}\right)\right)}-\right. \\
\left.\frac{1}{1+\exp \left(-200 \times\left(s_{\text {height }}-\text { Limit }_{\text {height }}\right)\right)}\right)
\end{gathered}
$$

$E_{\text {Size }}$ は縦幅が Limit $_{\text {height }}$ より小さい, もしくは横幅が Limit $_{\text {width }}$ より 小さいコマが1つでも存在すると 0.5 を超える.

\subsection{3 縦横比による評価}

コマは正方形に近いほど汎用性が高く, 中に絵を描きやす い.そこで，式（24）を用い評価することで，正方形に近 いコマを生成されやすくする，ただし，ページ中のコマの集 合を $S$ とし, コマの数を $n$, コマsの横幅を $s_{\text {widt }}$, 縦幅を $s_{\text {height }}$ とする.

$$
E_{\text {Square }}=\frac{\sum_{s \in S}\left(s_{\text {height }} \times 1.414-s_{\text {widht }}\right)^{2}}{n}
$$

\subsection{4 コマ同士の境界線による評価}

漫画を読む際，注目しているコマの枠線が次のコマではな い同方向な枠線と近い場合, どういった順番で読むべきか混 乱し，読みにくい漫画となってしまう。図6に例を示す。図 6の例でいうと，現在ページの右上の(1)コマを読んでいると したとき, 図6左のようなぺージの切り方を行った場合, 次 に読み進める順番が，下であるのか左であるのかわかりにく い.これは, 左図のLine2 と Line3の方向とX座標が同じた めである。このような状態を解消するためには，図6右のコ マ割のように, Line2 と Line3のX座標が同じになることを 避けなければならない。 そこで, 式 (25) の評価関数を用い, 同じ方向を向いている他のページ分割点とX座標または $\mathrm{Y}$ 座標が近くならないようにする。ただし, ページ分割点の数 を $n, i$ 番目のページ分割点 $p(i)$ の $\mathrm{X}$ 座標, $\mathrm{Y}$ 座標, 方向はそ れぞれ $p(i)_{x}, p(i)_{y}, p(i)_{d}$ とする.
読みにくい例

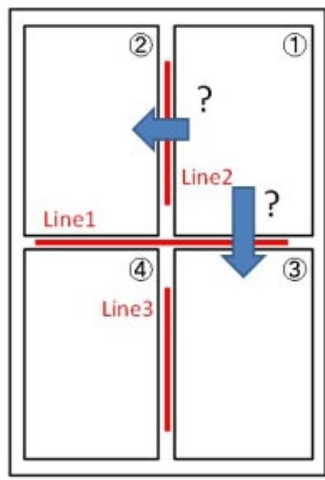

縰のラインが揃っているため どちらの方向に読み進めれぱ いいのかわかりにくい
改善例

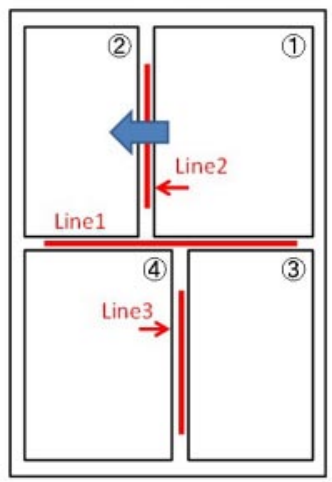

繸のラインが揃うのを避けることで 読む方向を分かりやすくする
図6 コマの境界線によって読みにくい例 
みと七匹のこどもやぎ(要約率0.6)を評価し, 別の被験者は,

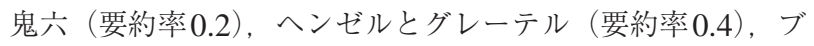
レーメンの町楽隊 (要約率0.6), おおかみと七匹のこどもや ぎ (要約率 0.8 ）を評価する。そのため, 同一の物語で同一 の要約率を評価している被験者は 5 人，1つの要約率につき 4 つの物語を評価するため, 1 つの要約率を 20 人の被験者が 評価することになる。

\section{4. 結果および考察}

アンケート結果から得られた, 質問 1 と質問 2 の評価とそ の母平均の $95 \%$ 信頼区間をそれぞれ表4と表 5 に示す。

Tukey-Kramer法を用いて, 表4と表5の結果を多重比較し た結果を，表6と表7に示す。

要約を行うことによるコマの充足性の変化を検証する。表 4から, 最も高い理解度が得られている要約率は未要約であ り, また, 未要約, 要約率 0.2 , 要約率 0.4 においては母平 均の $95 \%$ 信頼区間の下限值が中央值（どちらでもない）で ある4を上回っていることがわかる. 同様の結果は表5の質 問 $2 て ゙ も$ 得られている。 このことから, 被験者は, 要約率 0.4 までの要約であれば, 生成されるコマは物語を表現する上で 十分足りていると感じており，物語を理解することができて いることがわかる，また，表6の結果から, 物語に対する理 解においては, 未要約と有意な差がある要約率は要約率 0.8 のときである。また，表7の結果から，質問 2 においても, 未要約と有意な差がある要約率は要約率 0.8 のきである. このことから, 要約率 0.6 までの範囲であれば, 物語の理解

表4 アンケート結果（質問1）

\begin{tabular}{|c|c|c|c|c|c|c|}
\hline & \multicolumn{5}{|c|}{ 要約率 } \\
\hline & & 0.0 & 0.2 & 0.4 & 0.6 & 0.8 \\
\hline \multirow{7}{*}{ 評価值 } & 7 & 6 & 6 & 1 & 1 & 0 \\
\hline & 6 & 8 & 6 & 10 & 3 & 4 \\
\hline & 5 & 6 & 5 & 3 & 7 & 8 \\
\hline & 4 & 0 & 2 & 1 & 2 & 0 \\
\hline & 3 & 0 & 1 & 3 & 6 & 1 \\
\hline & 2 & 0 & 0 & 2 & 1 & 4 \\
\hline & 1 & 0 & 0 & 0 & 0 & 3 \\
\hline \multicolumn{2}{|c|}{ 上限值 } & 6.37 & 6.25 & 5.67 & 5.03 & 4.78 \\
\hline \multicolumn{2}{|c|}{ 平均值 } & 6.00 & 5.70 & 4.95 & 4.40 & 3.90 \\
\hline \multicolumn{2}{|c|}{ 下限值 } & 5.63 & 5.15 & 4.23 & 3.77 & 3.02 \\
\hline
\end{tabular}

表5 アンケート結果（質問2）

\begin{tabular}{|c|c|r|r|r|r|r|}
\cline { 3 - 7 } \multicolumn{2}{c|}{} & \multicolumn{6}{|c|}{ 要約率 } \\
\cline { 2 - 7 } \multicolumn{1}{c|}{} & 0.0 & 0.2 & 0.4 & \multicolumn{1}{c|}{0.6} & 0.8 \\
\hline \multirow{4}{*}{ 評価值 } & 7 & 7 & 5 & 3 & 0 & 0 \\
\cline { 2 - 7 } & 6 & 9 & 4 & 6 & 3 & 4 \\
\cline { 2 - 7 } & 5 & 1 & 7 & 6 & 6 & 1 \\
\cline { 2 - 7 } & 4 & 0 & 3 & 3 & 4 & 1 \\
\cline { 2 - 7 } & 3 & 1 & 1 & 0 & 5 & 8 \\
\cline { 2 - 7 } & 2 & 2 & 0 & 1 & 2 & 2 \\
\cline { 2 - 7 } & 1 & 0 & 0 & 1 & 0 & 4 \\
\hline 上限値 & 6.49 & 6.01 & 5.83 & 4.74 & 4.07 \\
\hline 平均值 & 5.75 & 5.45 & 5.10 & 4.15 & 3.25 \\
\hline 下限值 & 5.01 & 4.89 & 4.37 & 3.56 & 2.43 \\
\hline
\end{tabular}

においては未要約と差があるとは言えないコマ割を生成する ことができるということがわかる，このことから，物語を要 約する場合, 要約率を 0.4 までにとどめておくことで, 未要 約と差があるとは言えないレベルで, 物語が理解できるコマ 割を生成できると考えられる.

各物語の質問 1 と質問 2 のアンケート結果の平均值を図 7 と図8に示す。図7から, どの物語においても, 要約率が低 ければ物語の理解度は保たれており, 要約率が高くなるほど 理解できなくなっていく傾向があることがわかる．本実験に

表6 Tukey-Kramer法による要約率ごとの比較（質問 1）

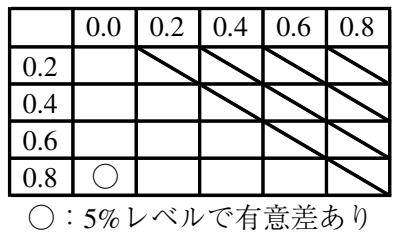

表7 Tukey-Kramer法による要約率ごとの比較（質問2）
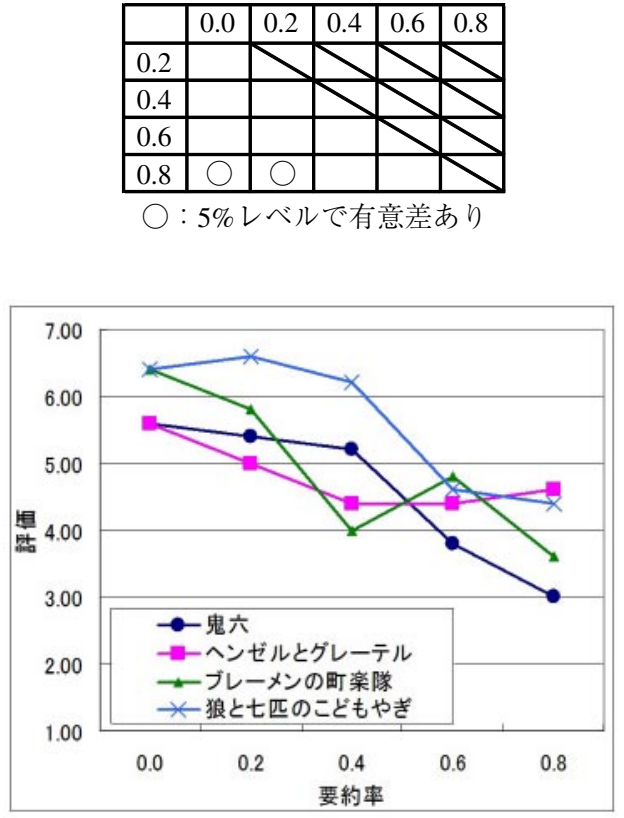

図7 各物語のアンケート平均値（質問 1）

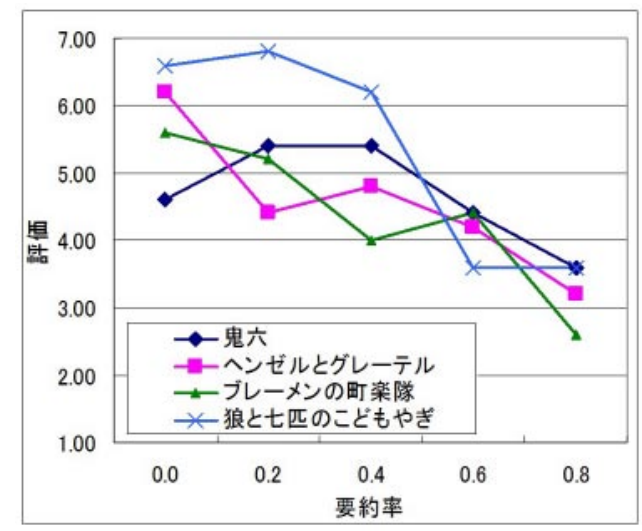

図8 各物語のアンケート平均値（質問 2） 
おいて, ヘンゼルとグレーテル, ブレーメンの町楽隊，おお かみと七匹のこどもやぎを知っている被験者は多いが, 鬼六 の物語をもともと知っている人は半数程度である.このこと から, 物語をもともと知っているかどうかに関係なく, 低い 要約率では物語を理解することができ, 要約率が高くなるに つれ理解できなくなっていくことがわかる. 同様の結果は図 8 の質問 2 の結果からも得られている.

要約された物語テキストがコマの大きさの妥当性に与える 影響について検証する。アンケート結果から得られた，質問 3 と質問 4 の評価とその母平均の $95 \%$ 信頼区間をそれぞれ表 8 と表 9 に示す. 表 8 から, 被験者が感じるコマの大きさの 妥当性は, 要約率0.6を除く全ての要約率で母平均の 95\%信 頼区間の下限值が中央值 (どちらでもない) である 4 を上回っ

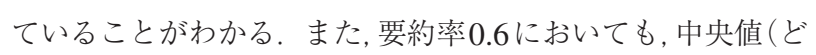

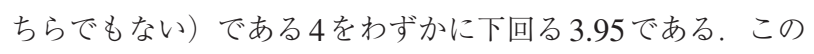
ことから, システムが生成するコマの大きさは物語テキスト の要約率に関係なく妥当であると考えられる。 また, 表 9 か ら, 被験者の要所要所でコマが大きくなっていると感じるか

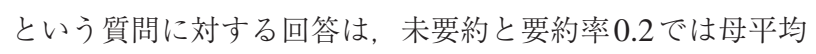
の $95 \%$ 信頼区間の下限值が中央值（どちらでもない）を上 回っていることがわかる。 また, 要約率 0.4 から要約率 0.8 での母平均の $95 \%$ 信頼区間の下限值は中央值（どちらでも ない）をやや下回る3.75を上回っている.このことから, 全ての要約率で, 重要な場面であるのにコマが大きくなって いないとは被験者は感じていないことがわかる，また，特に 低い要約率では, 被験者は重要な場面でコマが大きくなって

表8 アンケート結果（質問3）

\begin{tabular}{|c|c|c|c|c|c|c|}
\hline & \multicolumn{5}{|c|}{ 要約率 } \\
\hline & & 0 & 0.2 & 0.4 & 0.6 & 0.8 \\
\hline \multirow{7}{*}{ 評価值 } & 7 & 1 & 1 & 1 & 1 & 1 \\
\hline & 6 & 9 & 4 & 8 & 5 & 9 \\
\hline & 5 & 5 & 11 & 3 & 6 & 0 \\
\hline & 4 & 2 & 2 & 6 & 2 & 5 \\
\hline & 3 & 3 & 2 & 1 & 5 & 5 \\
\hline & 2 & 0 & 0 & 1 & 1 & 0 \\
\hline & 1 & 0 & 0 & 0 & 0 & 0 \\
\hline \multicolumn{2}{|c|}{ 上限值 } & 5.70 & 5.46 & 5.55 & 5.25 & 5.45 \\
\hline \multicolumn{2}{|c|}{ 平均值 } & 5.15 & 5.00 & 4.95 & 4.60 & 4.80 \\
\hline \multicolumn{2}{|c|}{ 下限值 } & 4.60 & 4.54 & 4.35 & 3.95 & 4.15 \\
\hline
\end{tabular}

表9 アンケート結果（質問4）

\begin{tabular}{|c|c|c|c|c|c|c|}
\hline & \multicolumn{5}{|c|}{ 要約率 } \\
\hline & & 0 & 0.2 & 0.4 & 0.6 & 0.8 \\
\hline \multirow{7}{*}{ 評価值 } & 7 & 1 & 0 & 2 & 0 & 0 \\
\hline & 6 & 7 & 6 & 4 & 8 & 7 \\
\hline & 5 & 8 & 7 & 6 & 3 & 3 \\
\hline & 4 & 2 & 2 & 1 & 3 & 5 \\
\hline & 3 & 1 & 4 & 6 & 4 & 3 \\
\hline & 2 & 1 & 1 & 1 & 2 & 1 \\
\hline & 1 & 0 & 0 & 0 & 0 & 1 \\
\hline \multicolumn{2}{|c|}{ 上限值 } & 5.65 & 5.24 & 5.30 & 5.24 & 5.15 \\
\hline \multicolumn{2}{|c|}{ 平均值 } & 5.10 & 4.65 & 4.60 & 4.55 & 4.45 \\
\hline \multicolumn{2}{|c|}{ 下限值 } & 4.55 & 4.06 & 3.90 & 3.86 & 3.75 \\
\hline
\end{tabular}

いると感じていることがわかる，これらの結果から，生成さ れたコマ割のコマの大きさは, 重要なコマは大きくなってお り，その他のコマの大きさについても十分妥当であると考え られる。なお，高い要約率で質問4の評価がわずかに下がっ ている理由として, 低い重要度の文, ひいてはコマを削除し たことにより, コマ同士の重要度の差が小さくなり, コマの 大きさに差が出にくくなったことが考えられる.

\section{5. おわり}

本研究では，ユーザの入力する物語テキストをもとに、コ マ数の調整を行えるコマ割生成システムの構築を行い, 要約 された物語テキストがコマ割生成に与える影響を調査した。

その結果, 物語の理解度において, 未要約と有意な差があっ たのは 8 割の要約率のみであり, また, 未要約から要約率 4 割までの要約では, 被験者から理解度を尋ねる質問に対して 肯定的な評価が得られた。このことから，物語を要約する場 合, 要約率を 4 割までにとどめておくことで, 物語が理解で きるコマ割を生成できると考えられる，また，コマの大きさ については, どの要約率に扔いても，比較的妥当な大きさで 描かれていることがわかった。

今後の課題として, さらにページを大幅に減らす必要があ る場合は, 1つのコマに複数の登場人物や動作を描く, 1 ペー ジあたりのコマ数を増やすなどして, 情報量を減らさないよ うにページを減らす必要があると考えられる。また, 漫画生 成の次の段階として, コマの内部に絵を描くため, 構図の決 定を行う機構を作っていく必要がある.

\section{参 考 文 献}

[1] 外務省：国際漫画賞,

http://www.mofa.go.jp/Mofaj/gaiko/culture/manga/index.html

[2] 熊野七絵, 廣利正代:「アニメ・マンガ」調査研究 - 地 域事情と日本語教材一, 国際交流基金日本語教育紀要 第 4 号, pp.55-69, 2008

[3] 小林由佳, 石若裕子：漫画設計支援システム POM（ソフ トウェア紹介, 〈特集＞最新コンパイラ技術とCOINSに よる実践)、コンピュータソフトウェア, Vol.25, No.1 (20080125), pp.82-88, 2008.

[4] 牧田知大, 田野俊一, 市野順子, 橋山智訓：抽象化と実体 化の双方向インタラクションを可能にする漫画製作支援シ ステム, ヒューマンインタフェースシンポジウム 2008, pp.1189-1194, 2008.

[5] Shamir, A. Rubinstein, M. Levinboim, T: Generating Comics from 3D Interactive Computer Graphics, Computer Graphics and Applications, IEEE, Volume 26 Issue: 3, pp.53- 61, 2006.

[6] K.Takashima and T.Onisawa: Generation of Scene Frame of Manga from Narrative Text, Proc. of the Kansei Engineering 
and Emotion Research International Conference 2010, pp.2223-2233, 2010.

[7] ChaSen: http://chasen-legacy.sourceforge.jp/

[8] CaboCha: http://chasen.org/ taku/software/cabocha/

［9］相良直樹, 砂山渡, 谷内田正彦: 重要文抽出を利用した テキストからのストーリー抽出, 情報処理学会研究報告. 自然言語処理研究会報告, Vol.2004, No.108（20041104）, pp.159-164, 2004.

[10］砂山渡, 谷内田正彦：文章の特徴を表すキーワードを発見 して重要文を抽出する展望台システム, 電子情報通信学会 論文誌. D-I, 情報・システム, I- 情報処理, Vol.J84-D-1, No.2 (20010201), pp.146-154, 2001.

[11] Inderjeet Mani：自動要約, 共立出版株式会社, 2003.

[12] 木島紗弥子, 曳野京子, 平川正人：物語からの絵の自動生 成, 言語・音声理解と対話処理研究会, Vol.49, pp.51-56, 2007.

[13] 金谷健一：これなら分かる最適化数学 基礎原理から計算 手法まで, 共立出版株式会社, 2005.

[14] 青空文庫：http://www.aozora.gr.jp

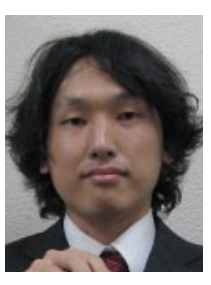

高嶋 航大（非会員）

2007 年 4 月筑波大学大学院システム情報工学 研究科知能機能システム専攻入学. 2009 年 3 月同大学大学院博士前期課程修了. 2009 年 4 月に同大学大学院博士後期課程に入学し現在 に至る，感性情報処理やソフトコンピュー ティングに関する研究に従事.

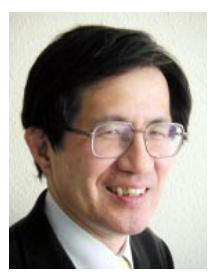

鬼沢 武久 (正会員)

1975 年 3 月東京工業大学制御工学科卒業. 1977 年 3 月同大学大学院理工学研究科制御工 学専攻修了. 現在, 筑波大学システム情報系 教授. 工学博士 (東京工業大学). 人間の主観, 判断, 認識, 感性, フィーリングを処理する 主観・感性コンピューティングに関心がある. 1987 年日本人間 工学会から橋本賞受賞. ISIS2005 でOutstanding Paper Award など. 2004 年から人工知能学会評議員. 2005 年から日本感性工 学会評議員. 日本知能情報ファジィ学会第 9 期会長. 2010 年か ら電子情報通信学会査読委員. 